\title{
REEMPLOYMENT RIGHTS OF THE VETERAN
}

Since the advent of the war in Korea and the repeated calls for a greater number of men to serve in the Armed Forces, the problem of reinstating the veteran in his former job upon his return from the service becomes of special importance. The provisions for the veterans' reemployment are found in the Selective Service Act of 1948.1 Many of the answers to the problems the veteran will face will be found in the numerous cases arising out of the attempt of the veteran of World War II to assert his reemployment rights under the Selective Training and Service Act of 1940; for very nearly the same provisions for reemployment, as amended, were reenacted in the 1948 Act. $^{2}$

The problems arising under the provisions of the Act of 1940 have not all been solved and the litigation continues at a steady pace. The purpose of this review is to summarize and analyze past decisions with an eye toward possible changes under the new provisions and to point out areas of future difficulty.

We shall consider the problem as it will be encountered by the veteran at three different stages upon his return to his old employment, i.e. (1) the difficulties he encounters in attempting to be reinstated with the employer, (2) under what circumstances and when may he later be discharged from that employment, and (3) the questions which arise in connection with his seniority and other benefits after he has been reinstated.

Certain general observations are necessary to an understanding of the problems faced by the courts in the decisions to be analyzed. First, any decision must necessarily be made in the light of the legislative policy underlying the provisions of the Act. Though this may be obvious, the underlying policy is not. If there were no collective bargaining agreements and no seniority systems the problems would be simple; for this much we know, that Congress wanted the veteran to have his old job back. Beyond that we can

50 U.S.C. App. 8459 (1948).

2 Provislons of the 1940 Act are found in 50 U.S.C. 8308 , as amended 56 Stat. 724 (1942), 58 stat. 798 (1944), 60 stat. 341 (1946). 
only speculate. There was a suggestion by Congressman May that the Act was intended to preserve the seniority of the railroad workers and that they would be able to count the time in the armed forces upon their retirement. ${ }^{3}$ The Senaters seemed te be less certain what the provisions really meant. The fact remains that there were many gaps in the law which could not be filled by anything the legislators had said either in committee or elsewhere. What those gaps were and how many of them remain will be pointed out.

\section{Problems Connected With the Initial Reinstatement}

The applicable provisions of the 1948 Act which must be considered at this point are in $\$ 9(\mathrm{~b})$ which reads as follows:

"In the case of any such person who, in order to perform such training and service, has left or leaves a position (other than a temporary position) in the employ of any employer and who (1) receives such certificate, and (2) makes application for reemployment within ninety days after he is relieved from such training and service or from hospitalization continuing after discharge for a period of not more than one year-... (B) if such position was in the employ of a private employer, such person shall- (i) if still qualified to perform the duties of such position, be restored by such employer or his successor, in interest to such position or to a position of like' seniority, status, and pay; ... unless the employer's circumstances have so changed as to mäke it impossible or unreasonable to do so." (The italicized words indicate provisions which were not in the 1940 Act.) ${ }^{\circ}$

The first observation to be made is that the reemployment provisions of the 1948 Act apply to inductees, enlistees, and reservists who have entered upon active duty. ${ }^{\circ}$ There are nearly identical provisions in $\$ 9(\mathrm{~b})$ (A) for those who were in the employ of the United States Government prior

- 86 Cong. Rec. 11702 (1940).

- 86 Cong. Rec. 10107-10109 (1940), Ben. Rep. No. 2002, 76th Cong., 3rd Sess. (1940).

- $\$ 9$ (a) merely provides that apon completion of satisfactory train. ing and service the veteran shall be giveu a certlficate to that effect, which is required under the quoted provisions.

- Inductees $89(\mathrm{~B})$; enllstees $89(\mathrm{~g})(1)$; and reservists $89(\mathrm{~g})(2)$. 
to their entry into the service. The Act is not retroactive, i.e. it does not apply to those who entered the Armed Forces prior to June, 1948, irrespective of the date of discharge. Consequently the cases have all arisen under the provisions of the Act of 1940.7

Generally the employer has not resisted the attempt of the veteran to be reinstated in his old job. Where such resistance has been met, it has most often come from employers outside the mass production industry-though not always. Perhaps the simplest explanation of this is that in the mass production industries the number of unskilled and semi-skilled workers is great, ${ }^{8}$ and to the employer one man is as good as another so long as he is physically able to perform the work.

Where the employer has resisted the attempt of the veteran to be reinstated the courts have generally construed the provisions liberally for the veteran. ${ }^{9}$ The courts could have just as easily gone the other way, for the provisions quoted above contain a safety valve in the words, "unless the employer's circumstances have so changed as to make it impossible or unreasonable to do so." In other situations courts have often utilized the word "unreasonable" to obtain desired results, but it has been a rare occasion under the reemployment provisions when the courts have fallen back on this safety valve. ${ }^{10}$ In fact, it has been held that it makes no difference that the particular job the veteran left is no longer in existence, unless it can be shown that no job of like seniority, status and pay exists. ${ }^{11}$

Two general reasons might be advanced as the basis for this attitude on the part of the courts. First, there is gen-

' Cushnier จ. Ford Motor Co., 89 F.Supp. 491 (E.D. Mich. 1950).

- This fact is recognized as one which gave rise to the demand for the senlority system. Mitchem, Beniority Clauses in Collective Bargaining Agreements, 21 Rocky Mt.L.Rev. 156 (1948).

- Said Justice Douglas in Fishgold $\nabla$. Sullivan Drydock \& Repair Corp., 328 U.S. 275 (1946) at 285, "This legislation is to be liberally construed for the benefit of those who left private life to serve their country in its hour of greatest need."

${ }^{10}$ Olin Industries $\vee$. Barnett, 64 F.Supp. 722 (S.D. Ill. 1946); Kent v. Todd Houston Shipbuilding Corp., 72 F.Supp. 506 (S.D. Tex. 1947). In beth cases the employer had ceased to produce war material and the courts held there was such a change of circumstances.

" Kent $\nabla$. Todd Honston Shipbuilding Corp., supra note 10. 
erally no out-of-pocket loss to the employer, (though there may be a hardship to a non-veteran) and secondly, most cases of this type arose immediately after the war while there was still a strong feeling that not enough could be done for the veteran. There would seem to be no reason to suppose that beth of these considerations will not be present to aid the veteran of the present confliet when he returns home.

The more specific problems that have arisen in connection with the above provisions are whether the veteran was an employee or an independent contractor, whether the position was temporary, whether seasonal and casual workers were excluded, whether the veteran held a "position" immediately prior to his entry into the service, and whether those holding elective positions were included within the provisions of the Act. ${ }^{12}$

The courts have strained to find the veteran was in the "employ" of the one with whom he seeks to get back his old job. They have found the following persons to be "employees": a rubbish hauler who came by once a week and who had never been regarded by his customers ${ }^{18}$ as their "employee", an attorney who collected accounts and received a galary and commission, ${ }^{14}$ and an attorney insurance adjuster who received regular wages. ${ }^{15}$ To pass on the question of whether a salesman is an employee or an independent

IN For a collection of there cases up to 1948 see Froed, The Reemployment Prootsions of the Belective Bervice Act, 6 Wash. \& Lee L. Rev. 48 (1848).

19 Karas T. Klain, 70 Fisupp. 469 (D. Minn. 1947).

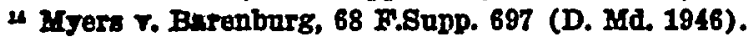

3 Jennings T. Mutual Casualty, 48 A.r.C. 107 (1947); accord, Dodd r. Tilliams, 68 F.Supp. 995 (D. Aris. 1946) (manager of a taxi busines8), Hejer r. Interboro Savings \& Loan Assoc., 166 F.2d 83 (3rd Cir. 1948) (a company attorney), Clark v. Housing Anthority of Port Orchard, 25 Trab.2d 119, 171 Pac.2d 217 (1946) (attorney who served as town houring arthority at a stipulatod monthly salary). When the veteran replnces a non-reteran in his old job he is entitled to the incumbont's rato of pas and not his old rato. Martin v. John 8. Doane Co., 68 F.Supp. 788 (D.Mass. 1947) (\$35 \& week to \$6,500 \& year), Baltor v. Bocker Roosing Co., 65 M.Supp. 688 (M.D. Ala. 1946), Troy v. Mohark Shop, 67 F.Supp 721 (M.D. Penns, 1946). (\$50 to $\$ 55$ per week). 
contractor, the courts have utilized the well-known "right of control" test with varying results.16

In considering whether the employment left was of a "temporary" nature, the courts have given the same liberal construction for the veteran and against the employer, and even where a veteran acknowledged in writing that his employment was temporary the court held it not to be.17 Most types of war plant work were held to be temporary-a problem which, in view of the dim prospect of cut-backs, will not confront the veteran of the Korean War to the extent it did the veterans of World War II. ${ }^{18}$ In the event the veteran had seasonal work, the test the courts have applied is to determine whether or not the veteran had a regular job to which he consistently returned during the specified season each year; if so, his employment was not temporary. ${ }^{19}$ In instances where the employee held a "working permit" from the union and could have been replaced at any time by an employee with a union "card", his employment was still held not to be temporary. ${ }^{20}$ Another problem has arisen in those cases where the employee's work was unsatisfactory, but the employer held him on a temporary basis until he was inducted. In such cases the veteran has not been allowed his old job.21

Recent magazine and newspaper articles indicate that employers may refuse to hire, and promote, and on occasion discharge those subject to be called under the draft laws. The problem of discharge is one not likely to arise in unionized industry under present collective bargaining agree-

${ }^{36}$ Lee v. Remington Rand, Inc., 68 F.Supp. 837 (S.D. Calif. 1946); Brown จ. Luster, 16E F.2d 181 (9th Cir. 1947).

${ }^{27}$ Grubbs .. Ingalls Iron Works, 66 F.Supp. 550 (N.D. Ala. 1946). The fact the employee had worked for a year after his acknowledgement of temporary employinent may have had considerable bearing on the result.

${ }^{28}$ Cases holding war work temporary: Olin Industries v. Barnett, 64 F.Supp. 722 (S.D. Ill. 1946) and Gualteri v. Sperry Gyroscope Co., Inc., 67 F.Supp. 219 (E.D. N.Y. 1946).

${ }^{23}$ Bocterle $\nabla$. Albert Robbins, Inc., 165 F.2d 942 (3rd Cir. 1947) (holding the summer job as hotel manager is not temporary); cf. U.S. ex rel. Unruh v. North American Creameries, 70 F.Supp. 36 (D. N.D. 1947) and U.S. ex rel. Stanley $\nabla$. Wimbish, 154 F.2d. 773 (4th Cir. 1946).

* Coon v. Llebmann Breweries, Inc., 86 F.Supp. 333 (D. N.J. 1949).

$n$ Marque v. Steru, 88 F.Supp. 306 (M.D. Penna. 1950). 
ments, and it is doubtful the courts will permit the discharge or placing of the prospective veteran on a temporary basis merely for the purpose of evading the provisions of the Act. In the case of the prospective veteran seeking employment, the possibility of being placed on a temporary basis may be to his advantage, for he may receive at least some employment-the employer being more willing to hire since there will be no legal obligation to reemploy.

In order to qualify for reemployment the veteran need not notify his employer that he is leaving to enter the armed forces, a union agreement to the contrary notwithstanding. ${ }^{22}$ But the veteran may have to make some concessions, e.g. it has been held he cannot compel reemployment in the same geographical location he left.23 It. is doubtful though whether, in the absence of special circumstances, a court would allow the employer to require the veteran to take a job any considerable distance from his old one, for such a holding would in many instances allow the employer to evade the provisions of the Act. The special circumstances of the case just cited were that the veteran's old job had been unionized in his absence and he was not a member of the union, nor did he desire to become one. The court answered with the only practical solution.

In line with the policy of aiding the veteran, one court has held a president of an insurance company who had been elected was entitled to his old job. Generally results have been the other way as to elected officials.24

Under the provisions of the 1940 Act it had been held that if the employer's business had changed hands, i.e. had been sold, the veteran was not entitled to reemployment.25 While the new provisions that the veteran is to be restored by his employer or ". . . his successor in interest" appear

* Anglin v. Chesapeake \& O.Ry.Co., 77 F.Supp. 359 (S.D. W.Va. 1948); cf. Bureau of Veteran's Employment Rights, U.S. Dept. of Labor Fleld Letter No. 12, Sept. 30, 1949.

* Bozar v. Contral Penna. Quarry \& Stripping Co., 73 F.Supp. 803 (M.D. Penne. 1947).

"s Houghton v. Texas State Life Ins. Co., 166 F.2d 848 (5th Cir. 1948); contra: Fraser จ. Shoberg, 65 F.Supp. 83 (E.D. Wash. 1946) (union offlicial whose term had expired) and Trusteed Funds, Inc. $\nabla$. Daceg, 160 F.2d 413 (1st Cir. 1947) (director of a corporation).

*. Dilauro, Conway v. Riley's Tavern, Inc., 48 A.L.C. 826 (1948). 
without any explanation, it would seem to bind such a vendee. Of course, there may have occurred other changes along with the sale of the business, but in such cases the courts can resort to the safety valve of "changed circumstances".

The 1948 Act has another provision which is new to the veterans' reemployment satutes. This provision, which follows immediately the part quoted in the first part of this division, is as follows:

"(ii) if not qualified to perform the duties of such position by reason of disability sustained during such service but qualified to perform the duties of any other position in the employ of such employer or his successor in interest, be restored by such employer or his successor in interest to such other position the duties of which he is qualified to perform as will provide him like seniority, status, and pay, or the nearest approximation thereof consistent with the circumstances in his case."

While no cases are known to have arisen under these provisions, it is highly probable that when such a case does come before the courts they will not hesitate to construe the provisions liberally in favor of the veteran. The basis of the prediction is the fact that any confiict which may arise will be between the veteran and employer, and the courts have consistently favored the veteran, even though not disabled. Add to that fact a natural sympathy for the cause of the disabled veteran and the prediction has even a sounder basis.

If the veteran enlists subsequent to the passage of the law in 1948 and after his term of enlistment expires, reenlists, he will not be allowed to claim reemployment rights under the Act. ${ }^{26}$ If his enlistment is the first subsequent

20 The provisions applicable are $\$ 9(g)(1)$ which reads: "Any person who, subsequent to the date of enactment of this title and while it is in effect, enlists in the armed forces of the United States (other than a reserve component) for not more than three years shall, if such enllstment is his first enlistment in the armed forces or the Coast Guard subsequent to the date of enactment of this title, be entitled, upon the expiration of his enlistment (including any extension thereof by law but not including any voluntary extension thereof) or upon his discharge under honorable conditions prior to the expiration thereof, to all the reemployment rights and other benefits provided for by this section in case of inductees." 
to the passage of the Act he will be entitled to such rights. A simple illustration of what is meant is as follows: if one enlists in the Armed Forces in 1949, he will be entitled to reemployment at his old job in 1952 upon his discharge; but if he should reenlist in 1952, he will not be entitled to such rights at the expiration of the second term. A difficult. problem might arise where one who enlisted subsequent to the 1940 Act, lct us say in 1941, reenlisted after the expiration of each three year term and finally is discharged in 1953. Can he assert the right to reemployment in his old job? Under the 1940 Act, one court held that where a veteran had reenlisted for a three year term after the expiration of the first, he was entitled to reemployment on the second discharge. By implication then in the supposed case, it umight be held that the veteran, after 12 years, would be entitled to reemployment, since his last enlistment was subsequent to the passage of the 1948 Act and that he was at all times within the protection of one of the Acts. Should such a case arise the court might use one of the following two provisos to bar the veteran: that he must be "qualified" to perform his old duties or that the employer's circumstances must not have so changed as to make it "unreasonable" to reemploy him.

Although the provisions of the Act are not explicit, it appears that if one is inducted after the enactment of the law, say for a period of two years and thereafter enlists for a period of three years, he would be entitled to reemployment. The emphasis here would have to be on the words "if such enlistment is his first enlistment", as distinguished from induction. In any instance where the veteran is otherwise entitled to reemployment, an extension of his term by law will not bar his claim. ${ }^{27}$

One other provision of the 1948 Act worthy of mention at this peint enables the veteran to obtain the services of the United States district attorneys without cost, provided however, that the district attorneys need not render such service if they are not reasonably satisfied that the person applying for such aid is entitled to the benefits. ${ }^{28}$ The dis-

- Iold.

* The applicable provision is 89 (d). 
cretion of the district attorney is wide and may on occasion be abused, ${ }^{29}$ yet the only alternative to the plan in the statute would seem to be for the government to pay the fees of private attorneys. Such a plan would hardly be subject to less abuse than the present one.

\section{Problems Connected With the Discharge of the Returned Veteran}

The apphicable provisions of the 1948 Act are found in $\$ 9$ (c) (1) which reads as follows:

"Any person who is restored to a position in accordance with the provisions of paragraph (A) or (B) of subsection (b) ... shall not be discharged from such position without cause within one year after such restoration."

These provisions are identical with those of the Act of 1940 and any problems arising are likely to be governed by the construction given by the courts to the 1940 provisions.

The problems as to discharge are closely allied to those as to lay-off which will be discussed in connection with seniority. As the Supreme Court has ruled, "discharge" under the Act "means termination of the employment relationship or loss of position." On the other hand, "... a person who has been laid off by operation of a seniority system and put on a waiting list for reassignment would hardly be considered as having been 'discharged'."30 Though this problem will be discussed more thoroughly in subsequent pages, it is worth noting here that had the Court held the word "discharge" te include "lay-off", the effect would have been to give the returned veteran a "super-seniority" since the Act prohibits discharge for one year.

2 In Iob v. Ios Angeles Brewing Co., 183 F.2d 398 (9th Cir. 1950) there seemed to be a bona fide dispute as to whether or not the contract with the Teamsters was ralld, and that question was one of the issues in the pleadings, yet the gorernment (Dept. of Justice) during the conrse of the trial admitted the validity of the contract and then on appeth just before default was to be entered against the veteran-appellants, the government asked to be substituted out the case on the ground that previous decisions of the Supreme Court foreclosed any question in the matter.

so Flshgold v. Sullivan Drydock \& Repair Corp., 328 U.S. 275 (1946) at 286. 
Two problems of importanco have arisen in connection with the discharge of the veteran: what is discharge witb "cause", and when has the veteran waived his right to rely upon the provisions against discharge.

In accord with the policy of aiding the veteran whenever possible, the burden has been placed on the employer to produce direct evidence of cause, e.g. of customers' complaints or "sassiness" of the employee. 31 The effect of this has been modified to some extent by the holdings that the cause for discharge need not be a "legal cause"-a term yet to be defined-but such cause as a fair-minded person may act upon. ${ }^{32}$ of course, what might be such cause as a fairminded porson may act upon will necessarily differ from one type of employment to another: this test which was applied to a professional baseball player is likely to yield a different result when applied to a worker in a factory. It might be difficult or impossible to prove a professional athlete is not as capable as he was before the war, since his ability is to some extent, measured by the skill of the opponents, and the employer should as a practical matter be allowed considerable discretion. On the other hand it may be easier of proof to show that one is not producing as much or doing the same quality of work in a factory.

One of the most serious problems to arise was whether the veteran, who returned to a job which had been unionized during his absence or after his return within the year, was beund to join the union in order to keep his job. The act itself seems to make no provision for this situation. In a very recent ease before the Circuit Court of Appeals in the Ninth Circuit, the court said that assuming the closed

a Cord v. New York Cleaning \& Dye Workg, 88 F.Supp. 704 (D. Conn. 1948).

- Sundra $\nabla$. St. Louis American Ieague Baseball, 87 F.Supp. 471 (FiD. Mo. 1949). The term "legal cause" as used in connection with the veteran's reemployment statutes seems to have originated in Keserich v. Carnegle-nlinols Steel Corp., 163 F.2d 899 (7th Cir. 1947) at 890. See also Basham v. Virginia Brewing Co., 66 F.Supp. 718 (W.D. Va. 1946) where use of valgar and protane langnage with customers contrary to company rules was held as a matter of law to constituto canse under the Act. In other conterts the Federal Courts have sald that in order for something to be a "legal cause" It must have been a ubstantial factor in bringing abeut harm. Kranss v. Greenburg, 137 F.ed 569, 572 (3rd Cir. 1948). 
shop contract was an existing valid agreement, servicemen who had been reemployed were under a duty to comply with its terms in order to retain their employment under the servicemen's employment statute, and that discharge for failure to do so was with cause. ${ }^{33}$ No doubt it would have been just as easy for the court to have said that the collective bargaining agreement was made subject to the provisions of the law affecting veterans and to have reached an opposite result; but at this point a new policy factor enters plus the fact that the hysteria of the war was over in 1949 when the case was decided, and the cry of "help the veteran" had grown dimmer.

There are several ways in which a veteran may waive any claim he has under the act. For instance if he submits the question of cause to an arbitration committee in accord witb a union contract he is bound by the committee finding. ${ }^{34}$ Similarly, by transferring to a different part of the industry,,$^{35}$ or by a refusal to accept a job of like seniority he waives his rights; but the employer may not promote the veteran to a new job and then discharge him for incompetence, since he still could have performed his old job and did not waive his right thereto in taking a new one. ${ }^{36}$

\section{What Is the Status of the Veteran Upon His Reemployment.}

By far the most important and seriously disputed question that will confront the veteran is the question of the status he will occupy when he is reemployed. The applicable provisions of the Act are as follows:

"(b) (B) ... such person shall .. be restored ... . to such position or to a position of like seniority, status or pay ;.... (c) (1) Any person who is restored to a position in accordance with the provisions . . shall be considered as having been on furlough or leave of $a b$-.

$\$$ Iob v. Los Angeles Brewing Co., Inc., 183 F.2d 398 (9th Cir. 1950); accord: Jensen v. Baker, 48 A.L.C. 956 (1949). on the grounds that it would have breached the employer's contract.

a Van Vloten v. News Syndicate Co., 50 A.L.C. 617 (S.D. N.Y. 1949).

* Walsh v. Chicago Bridge \& Iron Co., 90 F.Supp. 322 (N.D. Il. 1949); Bowen จ. Home Beneficial Life Ins. Co. 50 A.L.C. 232 (1950) (waiver by refusal to accept a position of like seniority).

* O'Neill v. American Stores, 50 A.L.C. 252 (1950). 
sence during his period of training and service in the armed forces, shall be so restored without loss of seniority, shall be entitled to participate in insurance or other benefits offered by the employer nursuant to established rules and practices relating to employees on furlough or leave of absence in effect with the employer at the time such person was inducted into such forces. . (2) It is hereby declared to be the sense of the Congress that any person who is restored to a position in accordance with the provisions of paragraph $(A)$ or $(B)$ of subsection $(b)$ should be so restored in such manner as to give him such status in his employment as he would have enjoyed if he had continued in such employment continuously from the time of his entering the armed forces until the time of his restoration to such employment." (The italicized portion is new to the 1948 Act.)

It is under like provisions in the 1940 Act that the veterans' problems assumed their most controversial form.

It cannot be over-emphasized that the problem of the veterans' status in reemployment involves a new and different policy censideration from that where the veteran is merely seeking to be reinstated; here the conflict, when it occurs, is between the veteran and the union. On the one hand, the policy is and will be to help the veteran find security upon his return from the service; on the other hand is a labor agreement which as the Supreme Court has said, ". . is a code for the government of an industrial enterprise and like all government, ultimately depends for its effectiveness on the quality of enforcement of its code."

Often the veterans' rights have been thought to come into conflict with the seniority system. Rightly or wrongly, the courts have curtailed that liberality of construction-so frequent in adjudicating disputes between the veteran and the employer-where such liberality would jeopardize a fundamental rule of industrial relations which has been relied upon so heavily by both labor and management.

Thougl this is not the place to explain the workings or the merits of the seniority principle, a few words will add to the understanding of the cases to be analyzed. It is said

n Trailmoblle Co. V. Whiris, 331 U.S. 40 (1947), Mr. Justice Jackson dissenting; Frankfurter J. concurring in the dissent. 
that the seniority system is second only to the wage and union security provisions in importance to the workers. Its function is to protect that large mass of unskilled and semiskilled workers in mass production industry who can be easily replaced, and to afford maximum security and reward to those who have rendered the longest service, and from the workers' standpoint it provides an objective standard of selection, eliminating favoritism and discrimination. In short, it provides security for the worker..$^{38}$ Though the seniority rights may vary under different agreements, as one court has said, "the" term seniority has a well recognized meaning. In the absence of specific limitation or enlargement, the right of seniority is the right of employees who have served the longest to a preference as respects continuous employment."

There are no cases to date under the provisions of the 1948 Act, but that part of the above provisions which was in the 1940 Act has at different times been given four different interpretations. They were (1) that the veteran was to be restored to a position of "super-seniority", ${ }^{40}$ (2) that he was to be restored to a position where he would have the identical seniority he had when he left.11 (3) that he be considered as having been on the active payroll during his time in the armed forces, 42 and (4) that he be considered as having been on the active payroll for some purposes and for others as having been in the same position as a non-veteran

- Mitchem, Beniority Otauses in Collective Bargaining Agreements. 21 Rocky Hit. L. Rev. 156 (1948). See also: "Union Agreement Provisiong", Dept. of Labor Buhl. 686 (1942) pp. 116-137.

* Droste v. Nash Kelvinator Corp., 64 F.Supp. 716 (E.D. Mich. 1946 ; at 721.

U.S. Sel.Service System, Local Bd.Memo. 190-A, May 20, 1944, Part IV, 1 (c); 14 L.R.R.M. 2615.

\& Hall v. Union Light, Heat \& Power Co., 53 F.Supp. 817 (E.D. Ky. 1944); see also: comment by William Green, Pres., of A.F.I. Inserted in Congressional Record, 86 Cong.Rec. 10091 (1940).

\& Mentzel v. Dlamond, 167 F.2d 299 (3rd Cir. 1948) the court sald, "The veteran is to be treated, $80 \mathrm{far}$ as benefits under the act are concerned, as though he had "worked every day at the plant"; See also:

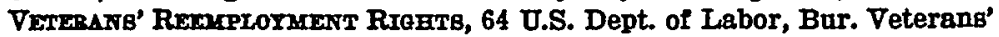
Reemployment Rights (1950). 
on leave of absence. ${ }^{13}$ It is true that the distinctions seem to be narrow but upon the assertion of a particular claim their importance is readily seen.

The consensus of opinion during the war-years seemed to be that the Act granted to the veteran a position of "superseniority"." In other words, the view was that upon his return the veteran would be entitled to take his old job back even though it meant the loss of a job by a non-veteran with greater seniority. This was the view taken by the administrative agency charged with the job of reinstating the veteran. ${ }^{45}$ The Director of Selective Service set forth his views as follows:46 "A veteran who has been reinstated to his former position cannot be displaced by another on the ground the latter has greater seniority rights. To permit such displacement would be to nullify the original reinstatement and thus deprive the veteran of his reemployment rights under the Act, and would be in effect a repeal of an Act of Congress." This interpretation was widely distributed and many rights were granted to veterans as a result. ${ }^{47}$ But many of the problems to arise were not foreseen and the legislators themselves seemed to have doubts as to the feasibility of the provisions. 48 There can be but little question that with the tightening up of industry after the war the result of this view would have been to destroy, temporarily,

a Monticue v. Baltimore \& O.Ry.Co., 91 F.Supp. 561 (N.D. Ohlo 1950), Brown v. Watt Car \& Wheel Co., 91 F.Supp. 570 (S.D. Ohio 1949), Flynn v. Ward Leonard Flectric Co., 84 F.Supp. 399 (S.D. N.Y. 1950).

" For a discussion of the "super-seniority" argument often referred to as a position of "absolute priority" see: Seniority and Re-Employment of War Veterans, 54 Yale L.J. 417 (1945).

4 Subsection ( $B$ ) 88 of the 1940 Act provided that the Director of Selective Service should establish a personnel division to render aid to veterans in replacement in thelr former positions. Public Law 26, 80th Congress, transferred to the Secretary of Labor functions of the Personnel Division of the Selective Training and Service Act on March 31, 1947. The Secretary of Lahor pursuant to the authority granted in the abore Act has established within the Dept. of Labor, the Veterans' Reemployment Rights Divglon, headed by a Director. The Act of 1948, 89 (h) leaves the work with the Dept. of Labor.

4 U.S. Sel. Service System, Local Bd. Memo. 190-A, supra note 40.

a Freeman v. General Motors Corp., 86 F.Supp. 527 (Đ.D. Mich. 1949) holding the company might withdraw rights granted on the basis of an interpretation of the Act by the Director of Selective Service which was suhsequently overruled by the Supreme Court.

4s 86 Cong.Rec. 10107-10109 (1940). 
a good share of what had been gained by the seniority system; it would have put older men out of work who had thought themselves secured by the seniority system. The question was then whether Congress had intended that the veteran was to have a job for one year regardless of the workings of the seniority system so that he might reestablish himself in civilian life, or whether he was to fit back into the seniority system.

The second of the four mentioned interpretations was given by a district court in Hall v. Union Light, Heat \& Power $C 0 .{ }^{19}$ in which that court said that the veteran returned to his job with the same seniority he had at the time of his departure. The practical effect of this position would have been a relative reduction in seniority for the veteran, for though his seniority would stand still while he was in the service, the seniority of those remaining on the job and taking his place would increase. Therefore if this view had been adopted, in many cases the veteran would have gotten little, if any, benefit from the law.

Today the lawyer and the veteran have four Supreme Court decisions to draw from. The first of those decisions, Fishgold v. Sullivan Drydock \& Repair Corp., ${ }^{50}$ expressly rejected the super-seniority argument and by implication rejected the position taken in the Hall case. Said the Supreme Court, "He [the veteran] steps back on [the seniority escalator] at the precise point he would have occupied had he kept his position continuously during the War." Thus, the veterans' seniority increased as if he had been on the job instead of in the armed forces. The actual holding of the case was that "lay-off" was not included in "discharge"; therefore an employer who had laid-off a veteran, favoring a non-veteran with more seniority, had not violated the statutory provisions on discharge.

In rejecting the "super-seniority" argument, the Court reviewed the administrative interpretations; and, finding that the National War Labor Board had placed a different

4 53 F.Supp. 817 (E.D. Ky. 1944).

* 328 U.S. 275 (1946). Justice Black dissenting on grounds unrelated to the merits of the case. 
interpretation ${ }^{\mathrm{s1}}$ upon the Act from that of the Director of Selective Service, it accepted that of the former for two reasons: first, they had been in adversary proceedings; and second, the fact there were various conflicting administrative rulings lent less credence to the contention that Congress had adopted one when the law was reenacted.

A point of interest in this litigation is that the District Court held for the veteran againgt the employer, but the Union, ${ }^{, 2}$ intervenor, appealed and the centroversy was, in it final stages, between the vcteran and the union. The unions, it would seem, are seeking to uphold their own order and enforce that "code for the government of industrial enterprise", i.e: while they are willing that the veteran should be placed back on his job and hold the same relative position of seniority that he left, they desire that in all other respects the collective bargaining agreement should bind the veteran.

Though the Fishgold case rejected the super-seniority argument and the position of the district court in the Hall case, it did not expressly decide whether the veteran was to be considered as being on the active payroll or as a nonveteran on leave of absence. Under either of these possibilities the seniority of the veteran might accrue along witl that of workers remaining on the job; but since the practice in a particular industry may be that those on leave of absence do not accrue seniority, the court by making no exception, impliedly adopted the third of the four mentioned interpretations, at least as to seniority.

In addition to the language above quoted the court in the Fishoold case said, ". . and no practice of employers or agreements between employers and union can out down the service adjustment benefits which Congress has secured the veteran under the Act." (Emphasis added.) The lower Federal courts have taken this language out of context and used it to declare invalid certain employer-union contracts.

a Bcovllle Mfg.Co., 21 War Lab. Rep. 200, 201 (1944).

- Various Labor Unions took great interest in the case and seroral Illed briefs as amlcus curae, among them J. 8. Padway and H. S. Thatchor for the A.F.I., Iee Presoman, of al. for tho C.I.O., and T. I. Mulholland, of al. for the Ry.Iabor Brecutives Arsoc. In support of the reipondent labor union. 
Other federal courts have declared the same contracts valid by using the language first quoted. In 1947 and 1948 five of these cases came before the Circuit Courts-four in the Third Circuit ${ }^{53}$ and one in the Ninth Circuit ${ }^{54}$-involving modification of collective bargaining agreements while the veteran was absent in the military service. The effect of the contracts was that union chairmen should have top seniority and in event of lay-offs union chairmen should be retained over all others. In each case a veteran was "laidoff" within the statutory year while union chairmen with less time with the company were retained. In the Third Circuit the court by a two to one vote held against the veteran in all cases, while the court in the Ninth Circuit held for the veteran. This court, as well as the dissenting judge in the Third Circuit, relied upon the language last quoted from the Fishgold case to the effect that collective bargaining agreements might not cut down the veterans' benefits, and pointed in addition to the language of the Act that the veteran "shall be so restored without loss of seniority."

In each of the cases the Union has intervened in the suit and in the Campbell case the Union intervenor appealed. The Supreme Court in Aeronautical Industrial District Lodge \#727 v. Campbell ${ }^{55}$ held that the veteran's rights under the provisions of the 1940 Act were not infringed by the modification of the agreements that existed at the time the veteran entered the service. In so holding the court relied upon the language of the Fishgold case that the veteran "steps back on [the seniority escalator] at the precise point he would have been had he kept his position continuously during the war." The court reasoned that if the veteran had not been in the service he would have been subject to the agreement as modified; therefore, he is now subject to it. Only by making the assumption that had the veteran remained on the job the contract would have been changed in the same manner it was, can the court reach the con-

w Gaweiler v. Elastic Stop Nut Corp., 162 F.2d 448 (3rd Cir. 1947), Koury v. Elastic Stop Nut Corp., 162 F.2d 544 (3rd̉ Cir. 1947), DiMaggio v. Elastic Stop Nut Corp., 162 F.2d 546 (3rd Cir. 1947), and Payne v. Wright Aeronautical Corp., 162 F.2d 549 (3rd Cir. 1947).

s Camphell v. Lockheed Aircraft Corp., 169 F.2d 252 (9th Cir. 1948).

337 U.S. 521 (1949). 
clus_sn it did. Yet the factual situation of $I o b v$. Los Angeles Brewing Co., Inc. ${ }^{5 B}$ illustrates that the situation might well arise where the remaining union members who are instrumental in making a change constitute only a minority of the union if veterans are counted.

Here again there is a conflict between the alleged rights of the veterans and the attempt of the union to strengthen its organization. It is not unusual to provide in labor contracts that certain employees shall head the seniority list. ${ }^{57}$ It is said the provisions for top seniority for union officials are necessary for the maintenance of a stable and experienced union leadership as it enables the union to maintain its organization when lay-offs occur. ${ }^{58}$ In the Campbell case the court inquired whether the act permitted contractual seniority effective on induction to be changed to a different contractual seniority and held that it did. In so holding the court said that Congress had neither defined seniority nor created a seniority system, but had recognized existing systems; therefore, since seniority rights derive their scope and significance from union contracts they are subject to change by modification of those contracts, and the date of employment is not made the inflexible basis for determining seniority rights.

In 1947, in between the Fishgold and Campbell cases, Trailmobile Co. $v$. Whirls ${ }^{59}$ came before the Supreme Court. Whirls had been an employee of a subsidiary company which consolidated with the parent Trailmobile Company. The original agreement upon the consolidation was that the employees of each company should retain their relative seniority. The employees of Trailmobile, being the majority, were dissatisfied with the agreement, voted to affiliate with a new union (the C.I.O.), ${ }^{60}$ and thereafter negotiated a new contract by which the former employees of the subsidiary company should have their seniority run from the time of the consolidation. This agreement so far as it affected

183 F.2d 398 (9th Cir. 1950).

-7 Droste v. Nash Kelvinator Corp., supra note 39.

* Matter of Glenn L. Martin Co., 19 War Lab. Rep. 263 (1944).

331 U.S. 40 (1947).

- The A.F.I. would not back the Trailmobile employees in the demand that others be deprived of seniority. 
Whirls, reduced his seniority at a time when he had been reemployed for over a year. The-Supreme Court held that the reduction of seniority after a statutory year does not violate the statute, since it does not discriminate against the veteran as such. But, said Mr. Justice Jackson, dissenting, ". . the right to discharge after the year is not unconditional where the employee is the beneficiary of a seniority plan. Of course, where employees have no seniority rights, the guarantee of one year's employment is their only right. But if a seniority system does exist, the Congress gave the employees protection within the framework of seniority plus a guarantee against demotion or termination without cause for one year. (Emphasis added) Fishgold v. Sullivan Drydock \& Repair Corp."61

The next and last Supreme Court case to consider the problem of the veterans' seniority rights was Oakley $v$. Louisville \& Nashville $R y{ }^{62}$ It was held in this case that the veterans' statutory seniority continues beyond the first year, with immunity against discriminatory changes. The veteran, said the Supreme Court, "assumes upon his reemployment, the seniority he would have had if he had remained in his civilian employment. His seniority status secured by this statutory wording continues beyond the first year of his reemployment, subject to the advantages and limitations applicable to other employees. The Act.added special statutory protection, for 1 year, against certain types of discharges or demotions that might rob the veterans' reemployment of its substance, but the expiration of that year did not terminate the right of the veteran to the seniority to which he was in the first instance entitled by :virtue of the Act's treatment of him as though he had.remained continuously in his civilian employment."

\footnotetext{
- Whirls had been discharged from his job after he had been expelled from the union on grounds that he had negotiated for himself through others than the union and acted in a way contrary and harmful to its interest by testing his rights in the courts. Said; Justice Jackson on this point, "One might have thought this an exaggerated fear conjured up in hostility to the union except that it is just what happened and instead of repudiating it now the union endorses its threat." "

0 338 U.S. 278 (1949). The court here acted on joint appeals and reversed the court in Haynes v. Cincinnati, New Orieans \& Tex. Ry., 171 F.2d 128 (6th Cir. 1948).
} 
The holdings of the Supreme Court in the principal case have been summarized as follows:"s "The seniority protected by statute at the end of the first year of reemployment is not then (a) automatically lost, (b) removed from protection of statute, (c) barred from enforcement in the courts by a 1-year statute of limitations, (d) opened to discriminatory reduction by employer or union, (e) made unchangeable in itself or its incidents in the absence of discrimination."

In recent months several cases have come before the Federal Courts. Two of these cases ${ }^{\text {ot }}$ may be dealt with as one for both involved an attempt of a veteran to claim time rendered in the servico as fulfilling the requirement of employment on the job in order to get vacations and vacation pay under a union agreement with the employer made in the veteran's absence. In the Monticue case the court in effect held that, though as to seniority the veteran is to be considered as having been on the active payroll, he is to be considered as having been on leave of absence in determining rights to other benefits. ${ }^{\circ 5}$ In 80 holding the court emphasized the language of the Act that the veteran, ". . shall bo :entitled to participate in insurance or other benefits offered by the employer.pursuant to established rules and practices relating to employees on leave of absence in effect with the employer at the time such person was inducted into such forces." (Emphasis added). Under this view while the veteran may have his seniority changed by modification of the collective bargaining agreement, not so with other benefits, as to then the agreement at the time he "was inducted" is controlling and that cannot be changed. Though the veteran might receive vacation pay on the basis of time spent in the service, it would bo only on condition the collective bargaining agreement expressly provided for such benefits. Had the court taken the view that the veteran

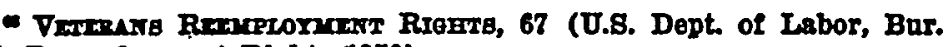
Vot. Roemployment Rights 1950).

- Monticue v. Baltimore O O.Ry.Co., 91 F.Supp. 661 (N.D. Ohio 1950) and Brown v. Watt Car \& Wheel Co., 91 F.Bupp. 570 (S.D. Ohio 1049).

- Thus the court took the fourth interpretation adverted to at the berining of this diviton. 
was to be considered as having worked on the job, he would have been entitled to the greater vacation benefits. Such a view would have been in accord with the Department of Labor's interpretation of the Campbell case. ${ }^{68}$

In the Monticue case it seems difficult to separate the "seniority rights" from "other benefits". The contract there provided that after 5 years continuous service the worker would be entitled to two weeks vacation rather than one, provided that $\mathbf{1 6 0}$ days of compensated work was performed in each year. The five year requirement thus grants greater benefits for greater seniority, even though the term "vacation" indicates "other benefits" than those normally associated with seniority.

Certiorari having been denied in the Brown case, there are now opposing decisions in different circuits, for the Third Circuit had already held that time in the service was. to be counted as time on the job and could be added in figuring out vacations based on length of service. This latter view relied upon the principle that the veteran is to return to the same position he would have occupied had he remained on the job, and the court said, "The veteran is to be treated. so far as benefits under the act are concerned as though he had worked every day at the plant."67

The same problem has arisen in a different form where the veteran has attempted to claim retroactive pay under a union contract for periods when he worked, yet was in the service on the day that the contract prescribed he must be on the active payroll in order to claim the retroactive.pay. It has twice been held ${ }^{68}$ that the veteran lost the money he would otherwise have received merely because he was not working on a particular day. These cases point out an easy means to evade the provisions of the Act by specifying in the employer-union contract that the veteran must be on the job on a particular day to claim any benefits. Of course the provisions would also have to be apphicable to other employees on leave of absence or who had quit their jobs at that date.

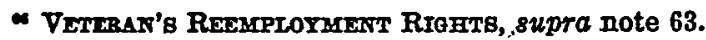

of Mentzel v. Diamond, supra note 42.

* Flynn v. Ward Ieonard Flectric Co., 84 F.Supp. 399 (S.D. N.Y. 1950) and Zagaiskl จ. Carboloy, Inc., 88 F.Supp. 162 (E.D. Mich. 1950). 
It is doubtful that the argument in favor of strengthening the unión organization by adhering to the collective bargaining agreement is applicable here. The union can gain nothing from such a technical construction of the collective bargaining agreement; the employer has a windfall at the veteran's expense. Perhaps the Third Circuit has recognized this, for where a union contract provided vacation pay could only be taken during the "current calendar year" they held a veteran who performed work before induction into the service did not have to comply with the contract requirement that to claim such vacation one had to be on the job "December 31".69

In another case, ${ }^{70}$ the Federal District Court for the Western District of Kentucky has held that under the statutory provisions relating to "seniority rights", veterans who were reemployed in their former jobs and who were thereafter promoted to jobs of different classifications were entitled to seniority in the new position as of the first date they performed their new jobs and not to retroactive seniority based on a strong presumption that had they remained at their work during the period of military service they would have been promoted during that period. Even a more pro-veteran court would probably fail to adopt such a presumption.

As has been indicated the Act of 1948 has a new provision that, "It is hereby declared to be the sense of the Congress that any person who is restored to a position in accordance with the provisions of paragraph (B) of subsection (b) should be so restored in such manner as to give him such status in his employment as he would have enjoyed if he had continued in such employment continuously from the time of his entering the armed forces until the time of his restoration to such employment."

One plaintiff has already attempted to invoke these provisions to count time in the service toward a vacation under a collective bargaining agreement made during his absence, 1948).

- McLaughlin จ. Union Switch \& Signal Co., 166 F.2d 46 (3d Cir.

Tregoroy จ. Loulsville \& N.R.R.Co., 92 F.Snpp. 770 (W.D. Ky. 1950); but cf. Conner 7. Pennsylvania R.R.Co., 177 F.2d 854 (D.C. Cir. 1949). 
but the court ruled against him since his induction was prior to the adoption of the provisions so that he did not come within them. ${ }^{71}$

Though the new section does not indicate on its face whether it was intended only to affect seniority or whether it was to include other benefits such as vacations and retroactive pay increases, the implication seems to be that it will only affect his seniority and that it was designed to affirm the Fishgold case rather than introduce any new change in the law. ${ }^{72}$ The old provisions remain that as to "other benefits" the veteran shall be governed by practices relating to employees on furlough or leave of absence. The only method by which the two provisions can be construed together with any degree of consistency is to interpret the new provisions as applying only to seniority, using seniority narrowly. Ally other construction will render nugatory the provisions that, as to "other benefits", the veteran is to be treated as being on leave of absence.

\section{Conclusions and Recommendations}

We have then, at the present time, a statute for the reemployment of veterans closely modeled after the reemployment statute for the veterans of World War II. There are some new additions to this statute which tend to aid in its construction, and yet there are still many gaps; those same gaps existed in the 1940 Act. The courts, as we have seen, have filled a part of them. There were no magic words in the Act that commanded the courts to follow one line of policy more than another. There were no enlightening clues as to what Congress had really intended, but on the contrary, an indication of confusion and lack of understanding.

7 Cushnier 7. Ford Motor Co., 89 F.Supp. 491 (E.D. Mich. 1950).

72 Sen. Rep. No. 1268, 80th Cong., 2d Sess. reports on $\$ 9(\mathrm{c})(2)$ as follows: "Statement of policy regarding application of the "escalator principle". The provisions of this legislation differ from those contained in the [1940 Act] in that it is specifically stated to be the intent of Congress that persons restored to Federal or private employment be restored so as to give them the status they would have enjoyed if they had remained in such employment..." The implication comes from the reference to the "escalator principle" which originated in the Fishgold case in connection with seniority. 
The courts adopted a liberal attitude when the veterans' conflict was with the employer; an attitude in accord with public policy and public opinion that the returned veteran should be given every "break", even though it entailed some sacriflce on the part of the employer. The Act did not command this; as shown, there was a safety valve. When that same conflict was with the unions, the courts curtailed their liberality and gave to the veteran only that which involved no risk of loss of anything the union had built up and no risk to those who remained in their employment during the war, when the veteran was called upon to defend the nation. The Act did not command this construction either, and the Director of Selective Service, who was given the original job of interpreting the Act, was definitely of the opinion that such construction was wrong. There would seem to be an inconsistency in this type of construction. Is there anything more sacred about unions than employers so that one cannot be called upon to make sacrifices and the other can? Surely if there was the legislators did not so indicate. The distinction then must be in the philosophy of the particular court; it is not in the Act.

The lower federal courts, trying somehow to follow both the statuto and the Supreme Court's decisions, liave watched too closely the collective bargaining agreements and have justifled their decisions upon a technical construction of the statute. In doing so they have often injured the veteran and incidentally contributed to the coffers of industry. While the instances are many, one example will serve to illustrate. Where a veteran has worked for two years under a plan providing for increased vacations after five years, and thereafter his place has been taken for two years by a non-veteran, who is replaced by the veteran on his return, the courts have held the veteran is not entitled to the increased vacation after reemployment for a year, yet at all times the employer has had someone on the job. The result is that the employer gets an employee for the full five years but does not have to provide extra vacation benefits for two or three more years. Should the courts continue to solve the veterans' rights on the basis of a rigid construction of the collective bargaining agreement, a veteran who had 
worked two years before induction and three after discharge might be held not to come within the provisions of a 5-year continuous service contract which provides for greater vacations-barring him becouse of the non-continuous aspect. Such a holding would be a windfall to the employer at the veteran's expense and work an undesirable forfeiture by the veteran.

Another example of even blinder adherence to the collective bargaining agreement is illustrated by those courts that have refused the veteran his retroactive pay where he was inducted a few days prior to the exact date specified in the agreement that he must be at work to claim such pay. Such a decision can benefit neither veteran nor union, but only industry. Paradoxically then, in their zeal to come to the aid of organized labor those courts have unwittingly aided the employer to the injury of the veteran.

A part of the solution to the problem lies in a final decision by Congress as to what the veteran is supposed to have been given. More specifically, was it intended that the veteran should come back to his job after discharge from the service and take that job subject to the same hazards of lay-off and loss of benefits and seniority to which he would have been subject had he not entered the service; or was it intended that he should be given something more than merely his job back, and if so how much more?

Once this major policy decision is made, the provisions of the statute, indicated by the decisions to be capable of numerous interpretations, must be made more explicit.

The labor union itself, in conjunction with the employer, can do much to eliminate these problems by making specific provisions in the collective bargaining agreements providing for the distribution of benefits to those who enter the military service. In view of the avowed intention of the present Administration to maintain a large military force, it will be necessary for both employer and union to adjust to the circumstance of employees entering and returning from the armed forces quite frequently. Collective bargaining agreements should be planned accordingly. 
Herewith is submitted a redrafting of important parts of the statute:

$\$ 9$ (c) (1) Any person who is restored to a position in accordance with the provisions of paragraph (A) or (B) of subsection (b) shall be considered as having accrued seniority during his period of training and service; shall be entitled to participate in insurance, vacations, and other benefits offered by the employer pursuant to established practices and rules relating to employees on furlough or leave of absence in effect with the employer at the time such person was inducted into such forces, provided however that whenever such person shall replace a non-veteran who has been employed for the purpose of filling the veteran's job, the time of such non-veteran shall be counted toward vacation benefits of the veteran, unless such non-veteran shall remain employed in some other capacity; and the veteran shall not be discharged from such position without cause within one year after such restoration to such employment, nor be laid-off within one year, so long as there remains employment which he can perform.

(2) After the expiration of the first year of such employment the veteran shall no longer be entitled to such super-seniority but shall be subject to the same hazards of employment as those of like seniority.

(3) Any person who is so restored under the provisions of paragraph (B) of subsection (b) shall not be denied any benefits to which he would otherwise be entitled by reason of his presence in the armed forces on a particular day or by reason of non-continuous employment.

These provisions can only be used if the attitude is taken that the man who leaves his job to take up arms at little pay and at the risk of his own life is entitled upon his return to his old job for one year without being subject to the usual hazards of employment so that he might reestablish himself. The necessary corollary of this position is that it may, though it will not in every instance, call for a sacrifice on the part of those who remain-employee, employer and union alike. It is the view of the writer that those who would not countenance such a provision are those who would place upon a few the burden of the nation's battles.

Ray Graves. 